\title{
Birth preparedness complication readiness and determinants among pregnant women: a community-based survey from Ethiopia
}

Teshale Abosie Ananche $e^{1,2}$ and Legesse Tadesse Wodajo $3^{3^{*}}$

\begin{abstract}
Background: Maternal death related to obstetric complications remains a great challenge in developing countries. Since these complications are not consistently predictable, it is important to plan different preventive approaches to overcome them when. As the information on birth preparedness, complication readiness, and predictors were limited in the study area, we conducted this study.

Methods: A Cross-sectional study involving 396 pregnant women was conducted from 1st April to 1st May 2018. Data were collected using a pre-tested structured questionnaire. Descriptive, binary and multiple logistic regression analyses were conducted in SPSS for windows version 20. $P$ values $<0.05$ were considered significant.

Results: Of 361 women interviewed (91\% response rate), birth preparedness and complication readiness were present in 24.10\% (87/361) of women. Maternal factors, age 18-19 (AOR=0.18; 95\% Cl (0.04,0.94)), 20-34 (AOR= $0.40 ; 95 \% \mathrm{Cl}(0.20,0.78))$, education, not able to read/write $(\mathrm{AOR}=0.36 ; 95 \% \mathrm{Cl}(0.15,0.85)$,read/write $(\mathrm{AOR}=0.41 ; 95 \%$ $\mathrm{Cl}(0.19,0.89)$ ), Muslim religion $(\mathrm{AOR}=0.40 ; 95 \% \mathrm{Cl}(0.18,0.85))$ income $\mathrm{ETB},<1000(\mathrm{AOR}=0.21 ; 95 \% \mathrm{Cl}(0.07,0.67)$ ), $1000-2000,(A O R=0.38 ; 95 \% \mathrm{Cl}(0.19,0.76))$, and the mothers' knowledge on key danger signs of postpartum $(A O R=0.48 ; 95 \% \mathrm{Cl}(0.26,0.90))$ were independent predictors of birth preparedness and complication readiness.

Conclusions: Educational status, age, religion, family income, and knowledge of obstetric danger signs were significantly associated with birth preparedness and complication readiness. The Government and other health sector partners should work to improve women's education, income, and focus on young age groups on pregnancy danger signs.
\end{abstract}

Keywords: Delivery, Birth preparedness, Complication readiness, Afar region, Ethiopia

* Correspondence: legesset2008@gmail.com

${ }^{3}$ Department of Public Health, College of Health Science, Arsi University, Assela, Ethiopia

Full list of author information is available at the end of the article

C C The Author(s). 2020 Open Access This article is licensed under a Creative Commons Attribution 4.0 International License, which permits use, sharing, adaptation, distribution and reproduction in any medium or format, as long as you give appropriate credit to the original author(s) and the source, provide a link to the Creative Commons licence, and indicate if changes were made. The images or other third party material in this article are included in the article's Creative Commons licence, unless indicated otherwise in a credit line to the material. If material is not included in the article's Creative Commons licence and your intended use is not permitted by statutory regulation or exceeds the permitted use, you will need to obtain permission directly from the copyright holder. To view a copy of this licence, visit http://creativecommons.org/licenses/by/4.0/. The Creative Commons Public Domain Dedication waiver (http://creativecommons.org/publicdomain/zero/1.0/) applies to the data made available in this article, unless otherwise stated in a credit line to the data. 


\section{Backgrounds}

Maternal mortality is an unsettled public health agenda [1]. A large proportion of mothers living in developing countries remain in need of improved living conditions [2]. As of 2015, the two regions with the highest Maternal Mortality Rate (MMR) were Sub-Saharan Africa and Oceania [3]. In Ethiopia, MMR remains high (412 deaths per 100,000 live births according to 2016 Ethiopian Demographic and Health Survey (EDHS)), with more than $73 \%$ of mothers in delivering at home without any help from skilled attendants [4].

Birth preparedness and complication readiness (BP/ $\mathrm{CR}$ ) is a method aimed at promoting timely access to skilled maternal and neonatal services. This approach has its tools and indicators for monitoring maternal as well as neonatal health [5]. BP/CR helps pregnant women and their families to actively prepare and make informed decisions related to delivery. In addition, the majority of relatives and the community at large also lack information on these signs. During the occurrence of complications, the unprepared woman and relatives spend an excessive amount of time to tackle the danger. For example, a series of issues like getting organized, collecting money, and finding transportation to the appropriate Hospital facility are all the sources of delay. In addition, further delays could also occur in a health-care facility for identifying a compatible blood donor in case of hemorrhage or obtaining written consent before the actual help [6-8]. According to studies conducted in some parts of Ethiopia, only 16.5 to $22 \%$ of pregnant women were found to be prepared for birth and complications [9-11] which is similar to other developing nations like Kenya and India [12, 13].

Despite all the benefits of preparation for childbirth and readiness for unseen complications, limited information is available on this issue in the Afar region, Ethiopia. Therefore, this study explored the degree of preparation and readiness for delivery related issues in the study area. As a secondary objective this study also identified factors associated with $\mathrm{BP} / \mathrm{CR}$.

\section{Methods}

\section{Study setting}

A community based cross-sectional study was conducted from April 1st to May 1st, 2018 in Amibara Woreda of Afar Region, Ethiopia. Amibara is one of 34 Woredas from the Afar Regional State and is located $280 \mathrm{~km}$ away from Addis Ababa, (the capital city of Ethiopia). It is found in Zone-3 (Geberesu Zone) administrative part that covers an area of 3994.00 Square Kilometre. Amibara Woreda has sixteen rural Kebeles and three Urban Kebeles [4].

According to the Central Statistical Agency (CSA) of Ethiopia, the estimated population of Amibara Woreda was 81,811in 2016 [4]. There is one hospital, four health centres, and eighteen health posts in the woreda. Most of the Afar population are pastoralists who rely on livestock production. The languages spoken are- Afarigna and Amharic. Only $7.7 \%$ of the urban population are literate with an overall (urban and rural) literacy rate of less than 3\%. The main religions in the area are either Islamic or Christianity whereas the predominant ethnic groups are Afar, Amhara, and Argoba [14].

\section{Study participants}

All pregnant women residing in the study woreda were the source population whereas 396 pregnant women living in selected kebeles were included in our study population.

The sample size was calculated based on a single population proportion formula. The total population of reproductive age women in Amibara woreda was about 35,056 , of which 904 were expected to be pregnant. From a previous study result in the Bale zone, it was assumed $29.9 \%$ of pregnant women were well prepared for delivery and complications [7]. Then take a 95\% confidence level and 5\% margin of error (d), the sample was 322 women. After a design effect of 2 , it gives 644 and 64 participants were added for a non-response rate to make 708. Finally, the sample size becomes 396.

The sampling procedure used was a multistage sampling method. Amibara woreda was chosen by lottery method (from the 34 woredas in Afar region), and its 19 kebeles were stratified into three urban and 16 rural.

After the total number of pregnant women in Amibara woreda was identified from a Health Extension Workers' registration book, the proportions of the pregnant women to be taken from the four selected kebeles were calculated. Then, in order to take one participant from one household, a household sampling unit to be drawn from each kebele was identified. The study units (Households) taken from each selected kebele were in proportion to the population size, and every unit was approached by the Systematic Random Sampling (SRS) method. Meaning, after the first household, to begin with, was selected randomly, a sampling fraction between the sample size and population size was used to recruit further participants. In case there were two or more eligible women in one household, only one was selected randomly. Absentees during three home visits made by interviewers were labeled as a non-response. Pregnant women who were seriously sick were excluded from the study. All eligible women in the household were then interviewed.

\section{Study variables}

The dependent variable was $\mathrm{BP} / \mathrm{CR}$ whereas the independent variables were grouped into three categories. 
These were socio-demographic factors in the first category obstetric factors in the second category and factors related to the awareness of a pregnant woman about the danger signs of pregnancy and delivery in a third category.

\section{Operational definitions}

Birth preparedness $(\mathrm{BP} / \mathrm{CR})$ is a preparation that is planned well before delivery. A woman was considered to be well prepared for birth if she has identified a place of delivery, skilled birth attendant, saved money, and identified the mode of transport ahead of delivery. A participant who fulfilled at least three of the above criteria was considered well-prepared. Complication readiness was defined as as-an awareness of pregnancy and delivery related health problems and was considered to be present when a woman made all the necessary plans for emergency situations. For example, the arrangement of (funds, transport, blood donor, and designated decision maker) in case of hemorrhage and loss of consciousness.

A skilled care provider/attendant is a professional caregiver who has the knowledge and skills to manage labor, childbirth, and the postpartum period. She must be able to recognize complications and refer to the woman or the newborn to a higher level of care if the complications require interventions beyond the skilled attendants' competence.

The postpartum period was defined as a time starting from the delivery of the placenta up to 6 weeks. A newborn/neonatal period refers to the first 7 days of the newborn's life.

\section{Measurement tools and definitions}

A pre-tested interview questionnaire was used for data collection. The questionnaire was adapted from a JHPIEGO tool for monitoring of birth preparedness and complication readiness and indicators for maternal and newborn health [5]. Data were collected on sociodemographic variables like age, marital status, residence (urban versus rural), ethnicity, religion, education, occupation, and average monthly family income.

The questionnaire also included inquiries on health problems related to the current pregnancy, danger signs of pregnancy, and awareness on issues of delivery and postnatal period which require referral.

A woman was considered to be knowledgeable on key danger signs of pregnancy, if she mentioned at least three of the eight key danger signs for pregnancy (vaginal bleeding, swollen hands/face, and blurred vision) spontaneously $[9,15]$. Likewise, a woman was considered as knowledgeable on the key danger signs of labor/ childbirth, if she spontaneously mentioned at least three of the five major danger signs for labor/childbirth (severe vaginal bleeding, prolonged labor $(>12 \mathrm{~h})$, convulsion and retained (placenta) $[9,15]$ or a-.

Mention of at least two of the four key danger signs of a postpartum period (severe vaginal bleeding, foulsmelling vaginal discharge, and high fever) spontaneously $[9,15]$. The women were also asked about their antenatal care visits and preferred place of delivery.

\section{Data processing and analysis}

Data quality was maintained by proper recruitment, training, and supervision of data collectors. Data were checked for completeness, accuracy, and consistency by the principal investigator, and corrective measures were taken during data collection. The data was then entered into EPI-Info version 7.2.1.0 software and subsequently exported to SPSS version 20 statistical programs for analysis. The data were cleaned and descriptive statistics (using frequencies) were computed for each variable. Besides, bivariate and multiple regression analyses were carried out to identify independent predictors. During the analyses $95 \%$ confidence interval (CI) for odds ratio $(\mathrm{OR})$ and $P$-value $<0.05$ were used in declaring statistical significance.

\section{Ethics approval}

The study was commenced after obtaining ethical approval from the Ethical Review Committee of Adama General Hospital and Medical College. Informed consent was obtained from all participants before the interview.

\section{Results}

\section{Sociodemographic characteristics}

During this study among 396 pregnant women identified 361 completed the interview (making a response rate of $91.00 \%)$. The mean age of the respondents was $29 \pm 3$ years.

Of the respondents $315(87.26 \%)$ were currently in marital union, 260(72.02\%) were urban and the remaining rural, 146(40.44\%) were from Afar ethnic group. Muslim religion followers were 166(45.98\%). Education status showed $147(40.72 \%)$ of respondents cannot read and write while $84(23.26 \%)$ were able to write and read, 151 (41.83\%) were housewives (Table 1).

\section{Obstetric characteristics of the participants}

About 316 (87.53\%) of respondents attended antenatal care in their current pregnancy. Concerning gestational age of the participants $249(68.98 \%)$ were less than three complete months while remaining were three or more. As of the parity of the participants, $82(22.71 \%)$, had zero, $161(44.60 \%)$ less than three and the remained more than three. Stillbirth history of the study women revealed $48(17.33 \%)$ had it. Two hundred ninety three $(92.72 \%)$ accessed advice from health professionals while 16(5.06\%) from Health extension Workers (Table 2). 
Table 1 Sociodemographic characteristics of pregnant women involved in Amibara Woreda, Afar Region, Ethiopia, 2018

\begin{tabular}{|c|c|c|c|}
\hline \multirow[t]{2}{*}{ Variable } & \multirow[t]{2}{*}{ Variable category } & \multicolumn{2}{|c|}{ Frequency } \\
\hline & & $\bar{N}$ & $\begin{array}{l}\text { Percent } \\
(N=361)\end{array}$ \\
\hline \multicolumn{4}{|l|}{ Residence } \\
\hline & Urban & 260 & 72.02 \\
\hline & Rural & 101 & 27.98 \\
\hline \multirow[t]{3}{*}{ Age category } & $18-19$ & 23 & 6.37 \\
\hline & $20-34$ & 270 & 74.79 \\
\hline & $35-49$ & 68 & 18.84 \\
\hline \multirow[t]{4}{*}{ Marital Status } & Single & 23 & 6.37 \\
\hline & $\begin{array}{l}\text { Married/in } \\
\text { union }\end{array}$ & 315 & 87.26 \\
\hline & Divorced & 10 & 2.77 \\
\hline & Widowed & 13 & 3.60 \\
\hline \multirow[t]{4}{*}{ Religion } & Orthodox & 118 & 32.69 \\
\hline & Catholic & 13 & 3.60 \\
\hline & Protestant & 64 & 17.73 \\
\hline & Muslim & 166 & 45.98 \\
\hline \multirow[t]{5}{*}{ Ethnic group } & Afar & 146 & 40.44 \\
\hline & Amhara & 77 & 21.33 \\
\hline & Oromo & 43 & 11.91 \\
\hline & Tigere & 16 & 4.43 \\
\hline & SNNPa & 79 & 21.88 \\
\hline \multirow{6}{*}{$\begin{array}{l}\text { Occupation of } \\
\text { the woman }\end{array}$} & Cattle production & 60 & 16.62 \\
\hline & House wife & 151 & 41.83 \\
\hline & Government employee & 87 & 24.10 \\
\hline & Private employee & 25 & 6.93 \\
\hline & Private business & 25 & 6.93 \\
\hline & Jobless & 13 & 3.60 \\
\hline \multirow{4}{*}{$\begin{array}{l}\text { Educational status } \\
\text { of the mother }\end{array}$} & Not read and write & 147 & 40.72 \\
\hline & Read and write & 84 & 23.26 \\
\hline & Primary & 51 & 14.13 \\
\hline & Secondary and above & 79 & 21.88 \\
\hline \multirow{3}{*}{$\begin{array}{l}\text { Monthly income of } \\
\text { the household }\end{array}$} & $<1000$ ETB & 48 & 13.30 \\
\hline & 1000-2000 ETB & 117 & 32.41 \\
\hline & $>2000$ ETB & 196 & 54.29 \\
\hline \multirow[t]{2}{*}{ Family size } & $<4$ & 253 & 70.08 \\
\hline & $>4$ & 108 & 29.92 \\
\hline \multirow{5}{*}{$\begin{array}{l}\text { Occupation of the } \\
\text { husband }\end{array}$} & Nomad & 86 & 23.82 \\
\hline & Farmer & 14 & 3.88 \\
\hline & Government employee & 185 & 51.25 \\
\hline & Private employee & 38 & 10.53 \\
\hline & Private business & 38 & 10.53 \\
\hline
\end{tabular}

a SNNP South Nations, Nationalities and Peoples
Table 2 Obstetric characteristics of pregnant women in Amibara Woreda, Afar Region, Ethiopia, 2018 ( $N=361)$

\begin{tabular}{|c|c|c|c|}
\hline \multirow[t]{2}{*}{ Variable } & \multirow[t]{2}{*}{ Variable category } & \multicolumn{2}{|c|}{ Frequency } \\
\hline & & $\mathrm{N}$ & $\%$ \\
\hline \multirow{3}{*}{$\begin{array}{l}\text { Gestational age of } \\
\text { the current pregnancy }\end{array}$} & $<3$ Months & 156 & 43.21 \\
\hline & 3-6 Months & 55 & 15.24 \\
\hline & $>7$ Months & 150 & 41.55 \\
\hline \multirow[t]{2}{*}{ Gravidity } & Gravida $<3$ & 249 & 68.98 \\
\hline & Gravida $>=3$ & 112 & 31.02 \\
\hline \multirow{2}{*}{$\begin{array}{l}\text { ANC visits in current } \\
\text { pregnancy }\end{array}$} & Yes & 316 & 87.53 \\
\hline & No & 45 & 12.47 \\
\hline \multirow[t]{4}{*}{ No. ANC visits(316) } & 1 time & 76 & 24.05 \\
\hline & 2 times & 126 & 39.87 \\
\hline & 3 times & 79 & 21.88 \\
\hline & 4 times & 35 & 11.08 \\
\hline \multirow{3}{*}{$\begin{array}{l}\text { Service providers of } \\
\text { current ANC }(N=316)\end{array}$} & Health professional ${ }^{\mathrm{a}}$ & 293 & 92.72 \\
\hline & Health Extension Worker & 16 & 5.06 \\
\hline & Don't know & 7 & 2.22 \\
\hline \multirow[t]{3}{*}{ Parity } & Para 0 & 82 & 22.71 \\
\hline & Para 1-3 & 161 & 44.60 \\
\hline & Para $>=3$ & 118 & 32.69 \\
\hline \multirow{2}{*}{$\begin{array}{l}\text { Stillbirth history } \\
(N=279)\end{array}$} & Yes & 48 & 17.20 \\
\hline & No & 231 & 82.80 \\
\hline \multirow{2}{*}{$\begin{array}{l}\text { Stillbirth (numbers } \\
\text { of times) }(N=48)\end{array}$} & 1 time & 44 & 91.67 \\
\hline & 2 times & 4 & 8.33 \\
\hline
\end{tabular}

${ }^{a}$ Health professional (clinicians, nurses, midwives ...)

\section{Knowledge of danger signs during pregnancy, labor/ childbirth, and postpartum time}

Among 361 pregnant women participated in this study, 277 (76.73\%) spontaneously mentioned at least one key danger sign. From two hundred seventy seven respondents, 210 (58.17\%) mentioned vaginal bleeding. Accelerated/reduced fetal movement 16 (4.43\%), water break without labor in $48 \mathrm{~h}(13.30 \%)$ and blurred vision 21 (5.82\%) were spontaneously mentioned (Table 3).

\section{Birth preparedness and complication readiness}

Proportion of mothers with BP/CR among the study groups in Amibara District of Afar Region in Ethiopia was $24.10 \%$. Among those respondent who knew about BP/CR, 296 (81.99\%) spontaneously identified and mentioned place of delivery, 230 (63.71\%) prepared essential items for clean delivery and postpartum period, 150 (41.55\%) identify skill provider, arranged blood donor 5 (1.39) followed by saving money; 159 (44.04\%) (Table 4). 
Table 3 Birth Preparedness and Complication Readiness among pregnant women in Amibara Woreda, Afar Region, Ethiopia, 2018. $(N=361)$

\begin{tabular}{|c|c|c|c|}
\hline \multirow{2}{*}{$\begin{array}{l}\text { Birth Preparedness and } \\
\text { Complication readiness }\end{array}$} & & \multicolumn{2}{|c|}{ Frequency } \\
\hline & & Number & Percent \\
\hline \multirow[t]{2}{*}{ Prepared well } & Yes & 87 & 24.10 \\
\hline & No & 274 & 75.90 \\
\hline \multirow{2}{*}{$\begin{array}{l}\text { Exposure to BPCR } \\
\text { Information }\end{array}$} & Yes & 319 & 88.37 \\
\hline & No & 42 & 11.63 \\
\hline \multirow{6}{*}{$\begin{array}{l}\text { Source of information } \\
\text { about BPCR }(n=319 \text {, } \\
\text { multi-response) }\end{array}$} & Health Professional & 217 & 60.11 \\
\hline & Health Extension Worker & 44 & 12.19 \\
\hline & $\begin{array}{l}\text { Trained Traditional Birth } \\
\text { Attendant }\end{array}$ & 9 & 2.49 \\
\hline & $\begin{array}{l}\text { Traditional Birth } \\
\text { Attendant }\end{array}$ & 24 & 6.65 \\
\hline & Media & 59 & 16.34 \\
\hline & Mothers & 94 & 26.04 \\
\hline \multirow{2}{*}{$\begin{array}{l}\text { Prepare essential item } \\
\text { or clean delivery }\end{array}$} & Yes & 230 & 63.71 \\
\hline & No & 131 & 36.29 \\
\hline \multirow{2}{*}{$\begin{array}{l}\text { Identify health facility } \\
\text { for childbirth }\end{array}$} & Yes & 296 & 81.99 \\
\hline & No & 65 & 18.01 \\
\hline \multirow[t]{2}{*}{ Arranged transport } & Yes & 60 & 16.62 \\
\hline & No & 301 & 83.38 \\
\hline \multirow[t]{2}{*}{ Saved money } & Yes & 159 & 44.04 \\
\hline & No & 202 & 55.96 \\
\hline \multirow[t]{2}{*}{ Arranged blood donor } & Yes & 5 & 1.39 \\
\hline & No & 356 & 98.61 \\
\hline \multirow{2}{*}{$\begin{array}{l}\text { Identify skilled birth } \\
\text { attendant }\end{array}$} & Yes & 150 & 41.55 \\
\hline & No & 211 & 58.45 \\
\hline
\end{tabular}

Factors associated with birth preparedness and complication readiness

Birth preparedness and complication readiness was less likely made in younger age of $18-19$ and 20 to 34 years old women than old age of 35 to $49,(\mathrm{AOR}=0.18,95 \%$ CI $(0.04,0.94))$ and $(\mathrm{AOR}=0.40,95 \% \mathrm{CI},(0.20,0.78))$ respectively. Women who have no knowledge of postpartum related complication were found less likely prepared for $\mathrm{B} / \mathrm{CR} \quad(\mathrm{AOR}=0.48,95 \%$ CI $(0.26,0.90))$ (Table 5).

\section{Discussion}

According to this study more than $75 \%$ of pregnant women were not well prepared for childbirth and its complications. The finding was low in comparison to the WHO standard which states every pregnant woman should have a birth plan [16]. However, it's relatively higher than findings of studies conducted in some parts of Ethiopia- (Sidama Zone (17\%) [10], Arsi Zone (16.5\%) [11], and Wolita Zone (18.3\%) [17]). But the result was nearly similar with that of South Wollo (24.1\%) [18], Adigrat of Tigray Region (22\%) [9], Basoliben in Amhara Region (26.9\%) [19]. However, it was far-less than findings from the studies performed in major cities of Ethiopia such as Dire Dawa, (54.7\%) [20] and Addis Ababa, (56.3\%) [21], and findings from other countries like India (47.8\%) [22] and Nigeria (82.1\%) [23], those variations could happen due to the difference in the study settings, socio-cultural characteristics, politicaleconomic features, and implementation of related health programs.

We know that learning has multidimensional influences on human life practice and behavior. In this study women who had no formal education $(\mathrm{AOR}=0.36,95 \%$; CI $(0.15,0.85))$ and those who can only read and write (AOR $=0.41,95 \%$; CI $(0.19,0.89)$ ) were less likely to be well prepared compared to those who had secondary level education. The finding was analogous to other studies conducted in different parts of Ethiopia and other countries [7, 10, 13, 22-25]. Educated women have more opportunities and a tendency for $\mathrm{BP} / \mathrm{CR}$ as education increases the acquisition of information. Because the majority of women (64\%) had no formal education [Table 1], an improvement of formal education at a young age could have the greatest maternal health benefit. As the current study setting is very remote (i.e 400-k meters away from Semera, the capital city of the Afar Regional State) with the less developed infrastructure it needs to improve access to health service and education.

Women who do not know $\mathrm{BP} / \mathrm{CR}[\mathrm{AOR}=0.48$; $\mathrm{CI}$ $(0.26,0.90)]$ were found to have fewer odds of being well prepared for childbirth and readiness for complications compared to those women who know. The result indicates more than $80 \%$ of the women reported [Table 3] they had the information (i.e awareness). However, the source of information was not the same. Of those who had information (42/319), 60.11\% received it from health professionals, (44/319) 12.19\% from Health Extension Workers [Table 3]. It seems the difference between health professionals and Health Workers as a source of information is wide. The gap still is seen between health education provision on complication readiness or knowledge about it like foul-smelling vaginal discharge, (47/ $361)$, [13.02\%], and convulsion [4.43\%], high-grade fever, (41/361), [11.36\%], [Table 4], compared to information on BP/CR, (319/361), (88.37\%), [Table 3]. This shows there is a need to improve ways of providing complete information when counseling about BP/CR.

Providing income generation and socioeconomic opportunities for women will have a good impact on $\mathrm{BP} /$ CR. The women/families who had less average monthly income were found to have less BP/CR scores. On the contrary, compared to women who have monthly income of more than 2000 ETB, those with a monthly 
Table 4 Characteristics of knowledge of danger signs of pregnancy among participants, Amibara Woreda, Afar Region, Ethiopia, 2018. $(\mathrm{N}=361)$

\begin{tabular}{|c|c|c|c|c|c|c|c|}
\hline \multirow[t]{3}{*}{ Variables } & \multirow{3}{*}{$\begin{array}{l}\text { Response } \\
\text { Yes Or } \\
\text { No }\end{array}$} & \multicolumn{6}{|c|}{ Awareness } \\
\hline & & \multicolumn{2}{|c|}{ Pregnancy } & \multicolumn{2}{|c|}{ Labor/child birth } & \multicolumn{2}{|c|}{ Postpartum } \\
\hline & & $\mathbf{n}$ & $\%$ & n & $\%$ & $\mathbf{n}$ & $\%$ \\
\hline \multirow{2}{*}{$\begin{array}{l}\text { Knowledge of Obstetric } \\
\text { Danger signs }\end{array}$} & Yes & 277 & 76.73 & 282 & 78.12 & 196 & 54.29 \\
\hline & No & 84 & 23.27 & 79 & 21.88 & 165 & 45.71 \\
\hline \multirow[t]{2}{*}{ Vaginal bleeding } & Yes & 210 & 58.17 & & & & \\
\hline & No & 151 & 41.83 & & & & \\
\hline \multirow[t]{2}{*}{ Blurred vision } & Yes & 21 & 5.82 & & & & \\
\hline & No & 340 & 94.18 & & & & \\
\hline \multirow[t]{2}{*}{ Swollen hand/face } & Yes & 139 & 38.50 & & & & \\
\hline & No & 222 & 61.50 & & & & \\
\hline \multirow[t]{2}{*}{ Convulsion } & Yes & 31 & 8.59 & & & & \\
\hline & No & 330 & 91.41 & & & & \\
\hline \multirow[t]{2}{*}{ Loss of consciousness } & Yes & 38 & 8.53 & 52 & 14.40 & 65 & 18.01 \\
\hline & No & 323 & 90.47 & 309 & 85.60 & 296 & 81.99 \\
\hline \multirow[t]{2}{*}{ Severe abdominal pain } & Yes & 81 & 22.44 & & & & \\
\hline & No & 280 & 77.56 & & & & \\
\hline \multirow[t]{2}{*}{ Amniotic fluid leak before labor start } & Yes & 48 & 13.30 & & & & \\
\hline & No & 313 & 86.70 & & & & \\
\hline \multirow[t]{2}{*}{ Accelerated/reduced fetal movement } & Yes & 16 & 4.43 & & & & \\
\hline & No & 345 & 95.57 & & & & \\
\hline \multirow[t]{2}{*}{ Severe vaginal bleeding } & Yes & & & 177 & 49.03 & 144 & 39.89 \\
\hline & No & & & 184 & 50.97 & 217 & 60.11 \\
\hline \multirow[t]{2}{*}{ Placenta not delivered in $30 \mathrm{~min}$} & Yes & & & 164 & 45.43 & & \\
\hline & No & & & 197 & 54.57 & & \\
\hline \multirow[t]{2}{*}{ Labor last $>12 \mathrm{~h}$} & Yes & & & 173 & 47.92 & & \\
\hline & No & & & 188 & 52.08 & & \\
\hline \multirow[t]{2}{*}{ Having high grade fever } & yes & & & & & 41 & 11.36 \\
\hline & No & & & & & 320 & 88.64 \\
\hline \multirow[t]{2}{*}{ Foul smelling vaginal discharge } & yes & & & & & 47 & 13.02 \\
\hline & No & & & & & 314 & 86.98 \\
\hline
\end{tabular}

income of less than $1000(\mathrm{AOR}=0.21,95 \%$; CI $(0.07$, $0.67)$ ), and 1000 to $2000(\mathrm{AOR}=0.38,95 \%$; CI $(0.19$, 0.76 ), were less likely to have BP/CR (Table 5). Similar findings were reported in other studies [11, 15, 25]. Hence, a better economic status might strengthen BP/ CR. Besides, women who were not aware of postpartum danger signs had less BP/CR (AOR = 0.48, 95\%; CI $(0.26$, $0.90)$ ). The finding was similar to other studies conducted in Ethiopia and Rural Uganda [7, 11, 26].

Maternity issues include a different spectrum of life about risks and successes. The logistic regression analysis for the current data revealed that those women of younger age groups were less prepared to birth and related complications [18-19, $(\mathrm{AOR}=0.18,95 \%$; CI $(0.04$,
$0.94))]$, and $[20-34,(\mathrm{AOR}=0.40,95 \% \mathrm{CI}(0.20,0.78))]$ when compared to (35-49. This was similar to findings from a study in Nigeria [23].

There is no argument that religion could have either a positive or negative influence on the use of health services. This study revealed Muslim women were less likely to be well prepared for birth and related complications $(\mathrm{AOR}=0.40,95 \% \mathrm{CI}(0.18,0.85))$ compare to Protestants. This may be related to the effect of religion on culture and the preferred method of delivery. However, further qualitative studies are required more to explore relations.

This study tried to minimize selection bias by employing by giving all eligible women in the community an 
Table 5 Factors affecting BP/CR, Amibara Woreda, Afar Region, Ethiopia, 2018. ( $\mathrm{N}=361)$

\begin{tabular}{|c|c|c|c|c|c|}
\hline \multirow[t]{2}{*}{ Variable } & \multirow[t]{2}{*}{ Category } & \multicolumn{2}{|c|}{ well prepared } & \multirow{2}{*}{$\begin{array}{l}\text { COR } \\
95 \%(\mathrm{Cl})\end{array}$} & \multirow{2}{*}{$\begin{array}{l}\text { AOR } \\
95 \%(\mathrm{Cl})\end{array}$} \\
\hline & & $\begin{array}{l}\text { Yes } \\
\mathrm{N}(\%)\end{array}$ & $\begin{array}{l}\text { No } \\
\text { N (\%) }\end{array}$ & & \\
\hline \multirow[t]{3}{*}{ Age } & $18-19$ & $2(8.70)$ & $21(91.30)$ & $0.19(0.04,0.87)$ & $0.18(0.04,0.94)^{*}$ \\
\hline & $20-34$ & $62(22.96)$ & $208(77.04)$ & $0.58(0.33,1.04)$ & $0.40(0.20,0.78)^{*}$ \\
\hline & $35-49$ & $23(33.80)$ & $45(66.20)$ & 1.00 & 1.00 \\
\hline \multirow[t]{4}{*}{ Religion } & Catholic & $5(38.46)$ & $8(61.54)$ & $1.11(0.33,3.81)$ & $0.42(0.11,1.67)$ \\
\hline & Muslim & $26(15.66)$ & $140(84.34)$ & $0.33(0.17,0.64)$ & $0.40(0.18,0.85)^{*}$ \\
\hline & Orthodox & $33(27.97)$ & $85(72.03)$ & $0.69(0.36,1.33)$ & $0.48(0.23,1.01)$ \\
\hline & Protestant & $23(35.94)$ & $41(64.06)$ & 1.00 & 1.00 \\
\hline \multirow[t]{4}{*}{ Maternal Education } & Not read and write & 19 (12.92) & $128(87.07)$ & $0.19(0.10,0.36)$ & $0.36(0.15,0.85)^{*}$ \\
\hline & Primary & $15(29.41)$ & $36(70.59)$ & $0.52(0.25,1.11)$ & $0.74(0.32,1.71)$ \\
\hline & Read/ write & $18(21.43)$ & $66(78.57)$ & $0.34(0.17,0.68)$ & $0.41(0.19,0.89)^{*}$ \\
\hline & Secondary and above & $35(44.30)$ & $44(55.70)$ & 1.00 & 1.00 \\
\hline \multirow[t]{3}{*}{ Income (ETB) } & $<1000$ & $4(8.33)$ & $44(91.67)$ & $0.18(0.06,0.51)$ & $0.21(0.07,0.67)^{*}$ \\
\hline & $1000-2000$ & $16(15.84)$ & $101(84.16)$ & $0.31(0.17,0.56)$ & $0.38(0.19,0.76)^{*}$ \\
\hline & $>2000$ & $67(34.18)$ & $129(65,82)$ & 1.00 & 1.00 \\
\hline \multirow[t]{2}{*}{ Knowledge of pregnancy related cxn. } & No & $15(17.86)$ & $69(82.14)$ & $0.61(0.33,1.16)$ & $1.12(0.45,2.78)$ \\
\hline & Yes & $72(25.99)$ & $205(74.01)$ & 1.00 & 1.00 \\
\hline \multirow[t]{2}{*}{ Knowledge Labor related cxn. } & No & $14(17.72)$ & $65(82.28)$ & $0.62(0.31,1.65)$ & $0.98(0.39,2.52)$ \\
\hline & Yes & $73(25.89)$ & $209(74.11)$ & 1.00 & 1.00 \\
\hline \multirow[t]{2}{*}{ Knowledge of PP cxn. } & No & $63(32.14)$ & $133(67.86)$ & $0.36(0.21,0.61)$ & $0.48(0.26,0.90)^{*}$ \\
\hline & Yes & $24(14.55)$ & $141(85.45)$ & 1.00 & 1.00 \\
\hline
\end{tabular}

* Statistically significant associations $p<0.05$, cxn Complication, COR Crude odds ratio, AOR Adjusted odds ratio

equal chance to be selected. The limitation is that associations do not demonstrate the cause and effect relationships as this is a cross-sectional study.

Besides, since this study focused on one district the results might not be conclusive to the region at large.

\section{Conclusions}

The prevalence of BP/CR in the study area was far less than the World Health Organization requirement. Women's educational status, average monthly family income, and women's knowledge of postpartum obstetric complications were independent predictors of $\mathrm{BP} / \mathrm{CR}$. Governmental and non-governmental organizations should strive to improve women's education, income, and awareness of birth-related complications.

\section{Supplementary information}

Supplementary information accompanies this paper at https://doi.org/10. 1186/s12884-020-03297-W.

\section{Additional file 1.}

\section{Abbreviations}

BP/CR: Birth preparedness and complication readiness; CSAE: Central Statistical Agency [Ethiopia]; EDHS: Ethiopian Demographic and Health Survey; EmOC: Emergency Obstetric Care; HDSS: Health and Demographic
Surveillance System; IAG: Inter-Agency Group; SMI: Safe Motherhood Initiative; TBA: Traditional Birth Attendants; TTBA: Trained Traditional Birth Attendants; UNFPA: United Nation Fund Population Activity; UNICEF: United Nations International Children's Emergency Fund; WHO: World Health Organization

\section{Acknowledgments}

The authors sincerely thank Amibara District Health Office staff for their cooperation in facilitating the data collection activities. The participants, the data collectors, and the supervisors of the study deserve deserve a lot of thanks!

\section{Authors' contributions}

TA. Generated the study concept, developed the design, collected the data, analyzed, and prepared the paper. LT involved in generating concepts, designing the study, analyzing the data, writing up the manuscript to the current level. The authors read and approved the manuscript.

Funding

Not applicable.

Availability of data and materials

The authors confirm the availability of the data and can be accessed on ethically reasonable request though the analyzed data is in the manuscript.

\section{Ethics approval and consent to participate}

Ethical and study protocol approval was obtained from the Ethical Review Committee of Adama General Hospital and Medical College. A letter of support was obtained from the Amibara Woreda Health Offices before undertaking the study and written informed consent was obtained from the respondents before the interview. For privacy and confidentiality, all interviews were conducted in private setting and all cautions were taken to ensure confidentiality. The right of the respondents to refuse to participate 
in the study from the beginning or quit at any step during the interview was informed and addressed. Finally, respondents were provided information on the importance of antenatal care and birth preparedness and complication readiness.

\section{Consent for publication}

Not applicable.

\section{Competing interests}

All authors declare there is no conflict of interest.

\section{Author details}

${ }^{1}$ Center of International Program ICAP, Addis Ababa, Ethiopia. ${ }^{2}$ Semera Regional Office, Semera, Afar Regional State, Ethiopia. ${ }^{3}$ Department of Public Health, College of Health Science, Arsi University, Assela, Ethiopia.

Received: 6 June 2019 Accepted: 29 September 2020

Published online: 19 October 2020

\section{References}

1. Hogan M, Foreman K, Ahn S, Naghavi M, Wang M, Makela S, et al. Maternal mortality for 181 countries, 1980-2008: a systematic analysis of progress towards millennium development Goal5. Lancet. 2010;375(9726):1609-23.

2. World Health Organization, UNICEF, UNFPA, World Bank. Trends in maternal mortality: 1990 to 2010: World Health Organization; 2012. Available from: http://www.who.int/reproductivehealth/publications/

3. WHO, UNICEF, UNFPA, World Bank Group, and United Nations Population Division. Trends in maternal mortality: 1990 to 2015: estimates by WHO, UNICEF, UNFPA, World Bank Group, and the United Nations population division. Geneva: WHO Document Production Services. WHO reference number: WHO /RHR/15.23; 2015.

4. CSA, ICF. Ethiopia demographic and health survey 2016. Addis Ababa and Rockville: CSA and ICF; 2016.

5. JHPIEGO. Maternal and neonatal health program: monitoring birth preparedness and complication readiness; tools and indicators for maternal and newborn health. Hopkins: Bloomberg School of Public Health, Center for Communication Programs, Family Care International; 2004. Available from: http://pdf.dec.org/pdf_docs/PNADA619.pdf.

6. Kakaire O, Kaye DK, Osinde MO. Male involvement in birth preparedness and complication readiness for emergency obstetric referrals in rural Uganda. Reproductive Health J. 2011;8:12 https://www.ncbi.nlm.nih.gov/ pubmed/21548976.

7. Markos D, Bogale D. Birth preparedness and complication readiness among women of the childbearing age group in Goba woreda, Oromia region, Ethiopia. BMC Pregnancy Childbirth. 2014;14:282 http://www.biomedcentral. com/1471-2393/14/282.

8. Urassa DP, Andrea B, Mganga F. Birth preparedness and complication readiness in Mpwapwa district, Tanzania. Tanzan J Health Res. https://doi. org/10.4314/thrb.v14i1.8.

9. Hiluf M, Fantahun M. Birth preparedness and complication readiness among women in Adigrat town, North Ethiopia. Ethiop J Health Dev. 2007;22(1):1420 10.1.1.492.2022\&rep=rep1\&type=pdf.

10. Hailu M, Gebremariam A, Alemseged F, Deribie K. Birth preparedness and complication readiness among pregnant women in Aleta Wendo, southern Ethiopia. PLoS One. 2011;6:e21432.

11. Kaso M, Addisse M. Birth preparedness and complication readiness in robe Woreda, Arsi zone, Oromia region, Central Ethiopia. Reprod Health. 2014;11: 55 http://www.reproductive-health-journal.com/content/11/1/55.

12. Mukhopadhyay DK, Mukhopadhyay S, Bhattacharjee S, Nayak S, Biswas AK, Biswas AB. Status of birth preparedness and complication readiness in Uttar Dinajpur District, West Bengal. Indian J Public Health. 2013;57(3):147-54. https://doi.org/10.4103/0019-557X.119827.

13. Cheptum J, Omoni G, Mirie W. Factors affecting birth preparedness among pregnant women attending public antenatal clinics in Migori County, Kenya. Biomed J Sci Tech Res. 2018;3(4):BJSTR.MS.ID.000929.

14. Central Statistical Agency [Ethiopia] and IOC Macro. Ethiopia demographic and health survey preliminary report 2011. Addis Ababa and Calverton: Central Statistical Agency and ORC Macro; 2011. p. 2-7.

15. Andargie $E$, Nigussie A, Wondafrash $M$. Factors associated with birth preparedness and complication readiness in southern Ethiopia: a community based cross-sectional study, Ethiopia. BMC Pregnancy Childbirth 2017:17:412. https://doi.org/10.1186/s12884-017-1582-3.

16. WHO. World health organization standard for maternal and neonatal care birth and emergency preparedness in antenatal care: integrated Management of Pregnancy and Childbirth (IMPAC); 2006.

17. Gebre M, Gebremariam A, Abebe TA. Birth preparedness and complication readiness among pregnant women in Duguna Fango District, Wolayta zone, Ethiopia. PLoS One. 2015;10(9):e0127570.

18. Btew Y, Awoke W, Chekol S, et al. Birth preparedness and complication readiness practice and associated factors among pregnant women, Northwest Ethiopia. Int Sch Res Notices. 2016, 2016:8. https://doi.org/10. 1155/2016/8727365.

19. Bishaw W, Aweke W, Teshome M. Birth preparedness and complication readiness and associated factors among pregnant women in Basoliben District, Amhara regional state, Northwest Ethiopia. Primary Health Care. 2014;4:4. https://doi.org/10.4172/2167-1079.1000171.

20. Musa A, Amano A. Determinants of birth preparedness and complication readiness among pregnant women attending antenatal care at Dilchora referral hospital, Dire Dawa City. East Ethiopia. Gynecol Obstet (Sunnyvale). 2016:6(2):356.

21. Tiku S. Awareness on birth preparedness and complication readiness among antenatal care clients in Federal Police Referral Hospital Addis Ababa, Ethiopia. Am J Health Res. 2015;3(6):362-7.

22. Agarwal S, Sethi V, Srivastava K, Jha KP, Baqui HA. Birth preparedness and complication readiness among slum woman Indory city, India. J Health Popul Nutr. 2010;28(4):383-91 PMID: 20824982.

23. Sabageh OA, Adeoye OA, Adeomi AA, Sabageh D, Adejimi AA. Birth preparedness and complication readiness among pregnant women in Osogbo Metropolis, Southwest Nigeria. Pan Afr Med J. 2017;27:74. https:// doi.org/10.11604/pamj.2017.27.74.7266.

24. Endeshaw DB, Gezie LD, Yeshita HY. Birth preparedness and complication readiness among pregnant women: a community-based cross-sectional study in Tehulederie district, Northeast Ethiopia; 2018. https://doi.org/10. 1186/s12912-018-0278-y

25. Debelew GT, Afework MF, Yalew AW. Factors affecting birth preparedness and complication readiness among pregnant women in Jimma zone, southwest, Ethiopia. Pan Afr Med J. 2014; http://www.panafrican-medjournal.com/content/article/19/272/full/.

26. Kabakyenga K, Östergren P, Turyakira E, Pettersson K. Knowledge of obstetric danger signs and birth preparedness practices among women in rural Uganda. Reprod Health. 2011;8:33 http://www.reproductive-healthjournal.com/content/8/1/33.

\section{Publisher's Note}

Springer Nature remains neutral with regard to jurisdictional claims in published maps and institutional affiliations.
Ready to submit your research? Choose BMC and benefit from:

- fast, convenient online submission

- thorough peer review by experienced researchers in your field

- rapid publication on acceptance

- support for research data, including large and complex data types

- gold Open Access which fosters wider collaboration and increased citations

- maximum visibility for your research: over $100 \mathrm{M}$ website views per year

At $\mathrm{BMC}$, research is always in progress.

Learn more biomedcentral.com/submissions 